\title{
Mathematics in the Historical Collections of École Polytechnique
} Part II

Frédéric Brechenmacher (École Polytechnique, Palaiseau, France)

Following the discussion developed in the previous issue of the EMS newsletter on the place of mathematics in the reserve of ancient books and in the museum collection of École polytechnique, the present paper is devoted to mathematics in the archives of École polytechnique.

\section{The archives}

When École polytechnique was created in 1794, its new library was given the responsibility of preserving some of the archives produced by the school, in addition to the rich collection of ancient books which had been gathered from revolutionary seizures, as described in the first part of this paper. ${ }^{1}$ The historical value of the collection of ancient books benefitted from early recognition, which, in turn, helped preserve the archives.

The historical, administrative, and scientific archives of École polytechnique shed important light on various aspects of the evolution of mathematics since the creation of the school. The administrative archives especially contain the reports of the committees in charge of the various aspects of the school's academic programs, such as the structure and organisation of the competitive entrance exams and of the school's curriculum, and their relation to the expectations of both the specialised Écoles d'application, where the students complete their applied studies, and of future employers of École polytechnique graduates - businesses, administrative offices, research organisations, etc. The issue of the roles attributed to the teaching of mathematics has been a key topic in the debates of the school's committees for more than two centuries [Belhoste, 2001].

When the school was founded in 1794, its main features were the competitive entrance examination, the importance of mathematics, and the association of technical and mathematical education with military education. 2 The founding professors ("instituteurs") of analysis and mechanics were Joseph-Louis Lagrange and Gaspard Riche de Prony. Descriptive and differential geometry was in the hands of Gaspard Monge, who

\footnotetext{
1 This responsibility was extended in the 19th century to the personal fonds donated by alumni and eventually in the 1930 s to all the institutional archives produced by the school. On the archives of École polytechnique and their history, see [Billoux, 1985], [Billoux, 1989], [Billoux, 1999], [Azzola, 2013].

2 For a short synthesis on the role played by mathematics in the educational purpose of the school from 1794 to 1850 see [Grattan-Guinness, 2005].
}

also served as director for two short periods. Each instituteur had an assisting adjoint, who were named "répétiteurs" after 1798. Among notable adjoints or répétiteurs in mathematics, one may cite Joseph Fourier, Auguste Comte, Edmond Laguerre, and Henri Poincaré. One major feature was the distinction made between teaching and examining so examiners were also appointed. For mechanics and analysis

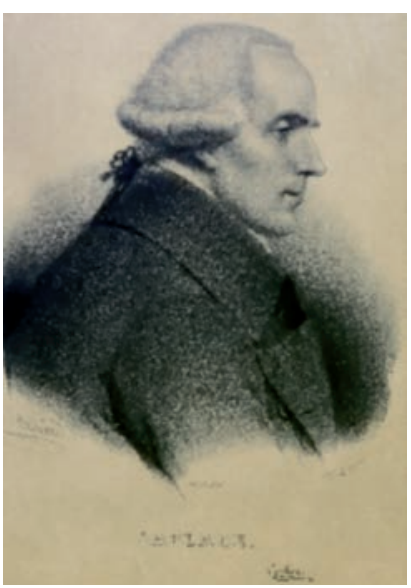

Pierre-Simon Laplace. (C) Collections École polytechnique. the initial examiners were Charles Bossut and Pierre-Simon Laplace.

Mathematics served as the dominant criterion in the entrance examinations [Belhoste, 2002]. Even more important was the focal role of mathematics in the curriculum. The view that among all the sciences necessary to both civil and military engineers, mathematics has the most considerable rank was already common before the Revolution when mathematical education was considered an integral part of military education. More and more, mathematical culture was being identified with military culture in opposition to the juridical culture of the "noblesse de robe". The interest in mathematics arose not merely because of its direct usefulness: mathematics, and especially instruction in mathematics, was seen to have valuable moral uses. It sharpened powers of reasoning and inculcated an orderly manner of thinking. Furthermore, the learning process of mathematics was considered to foster habits of work, self-control, and discipline.

While the school had originally been conceived as the one and only institution to train engineers, the impracticality of the vision was soon recognised and the role of the school was thus changed in 1795 to that of a preparatory institution for the other schools, which were organised into a collection of "écoles d'application". This change would have important consequences for the roles attributed to the teaching of mathematics, especially through the influence of Laplace [Belhoste, 1994]. For six weeks in 1799 Laplace performed as Minster of the Interior. He proposed that the school have a governing council, the "Conseil de Perfectionnement", to supplement the "Conseil d'Instruction" on teaching details, and 
a "Conseil d'Administration" for management. Laplace was one of its founding members, and he exercised much influence there, in particular reducing the time given to Monge's descriptive geometry and transferring much of it to mechanics and analysis. This opposition was led mainly by Laplace's desire to confine the programmes at École polytechnique to teaching general theories, which would then be applied in the other more specialised schools. This kind of difference over curriculum policy in the school would continue for a long time: the archives of the reports of the school's councils highlight that the issue of the roles attributed to mathematics fuelled a never-ending tension in the school curriculum, between the general and the special, and between the theoretical and the applied. ${ }^{3}$

École polytechnique's archives do not only shed light on the school's academic programs but also on the more general evolution of the French educational system. Because of the reorganisation and centralisation of the system of state technical schools as "écoles d'application" for École polytechnique in 1795, the standards and practices of the school were spread to other schools beyond the artillery and military engineering school. École polytechnique actually came to play a central role in French education in serving as the model for the French system of "grandes écoles". The Polytechnique, coupled with the Revolutionary and Napoleonic attempts to create a centralised, uniform system of education, did much to impose national standards of mathematical instruction in France and abroad.

The administrative archives of École polytechnique also contain the registration files ("fiches matricules") of all the students of the school. These files have been both digitalised and type-scripted in a database which is publicly available online for the time period 1794-1943. ${ }^{4}$ In addition to administrative information about the schooling of each student, including their entrance and exit rankings, these files provide biographical information about their genealogy, physical descriptions (complemented by a photograph after 1861), information about the école d'application the student joined after the Polytechnique and, quite often, details about professional careers. These files therefore provide crucial information for historians of mathematics. They especially shed light on the diversity in the careers of polytechnicians and, thereby, on the diversity of practitioners of mathematics over time.

The scientific archives of École polytechnique provide a lot of information about the courses of mathematics since the creation of the school, as well as about other academic activities such as the publication of the Journal de l'École polytechnique, which was initially established to fulfil the requirement of publishing lecture courses,

3 See [Belhoste, 2001] and, for a case study at the time of World War I, [Gilain, 2014].

4 According to French legislation on archival materials, only the registration files of students who graduated more than 75 years ago can be made public. To access the registration file database, see https://bibli-aleph.polytechnique.fr. but soon evolved into an academic journal publishing genuine research, mostly (and eventually solely) in mathematics, ${ }^{5}$ as well as the activity reports of the two mathematics laboratories of the school, the Laurent Schwartz Mathemat-

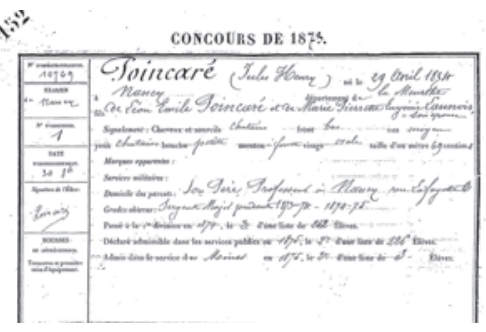

The registration file of Henri Poincaré in 1873. @ Collections École polytechnique. ics Centre (CMLS), created in 1965, and the Centre of Applied Mathematics (CMAP) created in 1974.

In the early years, several courses appeared at first in the school's journal, and later as books edited by Paris publishers. The archives allow us to compare this published material to the courses that were actually taught to students, which are documented by handouts that were at first copied by hand and later reproduced by authography or other techniques. These hand-out copies allow

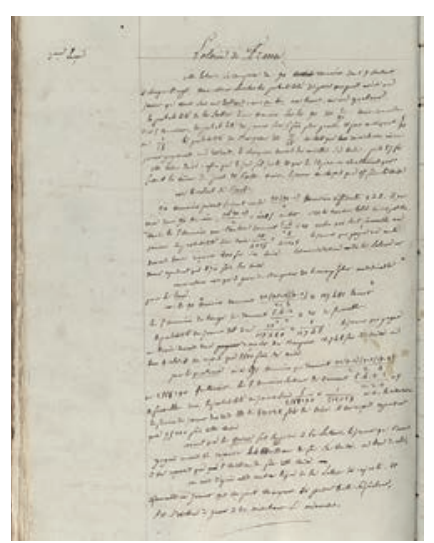

Manuscript of François Arago's course on social arithmetics, 1815 . (c) Collections École polytechnique.

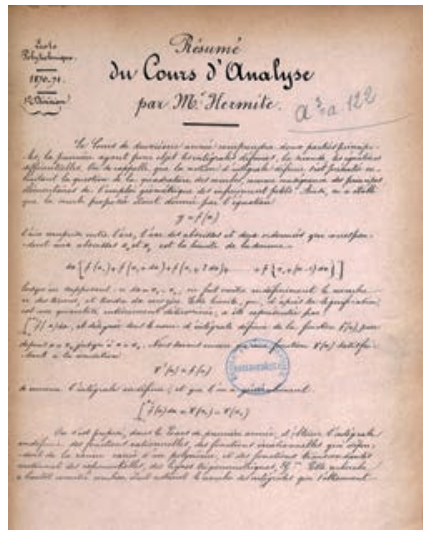

Manuscript of an abstract of Charles Hermite's course on analysis, 1870-1871. (C) Collections École polytechnique.

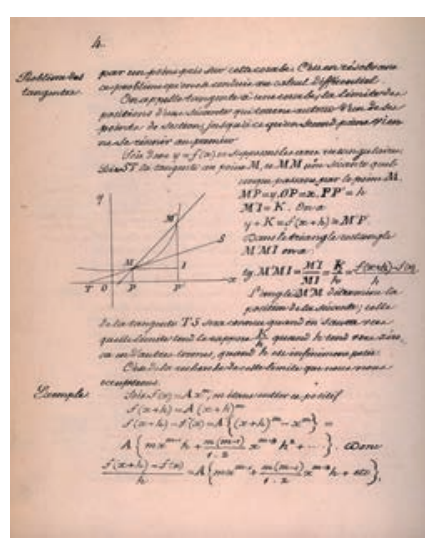

Manuscript of Joseph Liouville's course on differential calculus, 1847. (C) Collections École polytechnique.

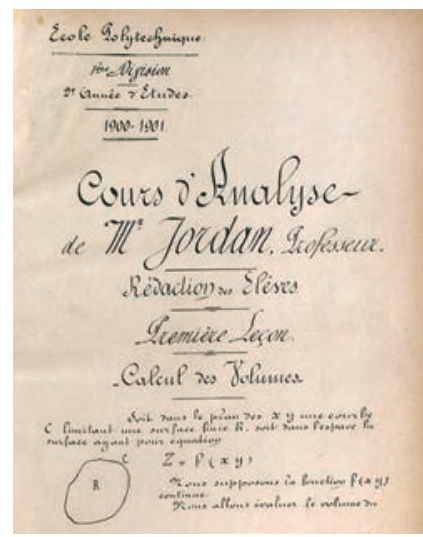

Manuscript of Camille Jordan's course on analysis, 1900-1901. (C) Collections École polytechnique.
5 The publication of the Journal de l'École polytechnique started in 1795 and stopped in 1939 until the journal was revived in 2013. See https://jep.math.cnrs.fr/index.php/JEP/. 
us to investigate in minute detail the evolution of specific aspects in the teaching of mathematics. To give just one example, the yearly editions of the handouts of Jacques Hadamard's course on analysis between 1912 and 1937 illustrate the gradual incorporation of vector calculus in the mathematics curriculum.

A number of historical studies have been devoted to several aspects of the teaching of mathematics at École polytechnique, such as with the development of a curriculum in calculus centred on the concepts of functions and limits from Lagrange to Cauchy, ${ }^{6}$ or with the role played by the three editions of Jordan's Cours d'analyse in providing new foundations to the theory of functions by incorporating the contemporary works of mathematicians such as Weierstrass or Peano. ${ }^{7}$ In addition to the handouts of the courses, the archives contain many other types of documents, manuscripts of mathematical memoirs, such as of Louis Poinsot and Jean-Victor Poncelet [Belhoste, 1998], notebooks of professors, such as Georges Humbert who was in charge of the Cours d'analyse from 1895-1920, reading notes on various mathematical publications taken by professors, such as Joseph Liouville [Verdier, 2010], handwritten notes taken by stu-

dents, such as August Comte [Gentil, 2002] or Benoit Mandelbrot, and manuscripts documenting the activities of the répétiteurs who were initially in charge of assisting the professors by organising individual oral examinations, and by supervising the works of the students.

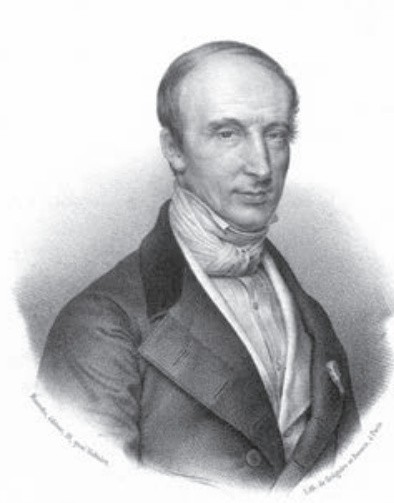

Augustin-Louis Cauchy. @ Collections École polytechnique.

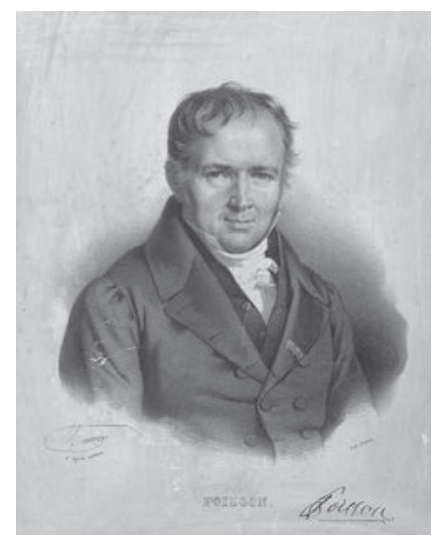

Siméon Denis Poisson. (C) Collections École polytechnique.

Principal academic staff in mathematics at École polytechnique from 1794 to 1959

\begin{tabular}{|c|c|c|c|c|c|}
\hline Analysis & & Geometry & & Mechanic & \\
\hline Prony & $1794-1814$ & Monge & 1794-1809 & Lagrange & 1794-1798 \\
\hline Ferry & 1794-1798 & Hachette & $1794-1815$ & Fourier & 1795-1797 \\
\hline Labey & 1799-1806 & Arago & $1810-1815$ & Garnier & 1798-1801 \\
\hline Ampère & $1807-1808$ & Leroy & $1816-1848$ & Lacroix & 1799-1808 \\
\hline Poinsot & 1809-1811 & De La Gournerie & 1849-1863 & Poisson & $1802-1814$ \\
\hline Labey & $1812-1814$ & Mannheim & $1864-1901$ & Ampère & 1809-1827 \\
\hline Cauchy & $1815-1829$ & Haag & $1901-1911$ & Mathieu & $1828-1832$ \\
\hline Arago & $1816-1829$ & d'Ocagne & $1912-1936$ & Navier & 1833-1836 \\
\hline Savary & 1830-1841 & Julia & 1936-1965 & Duhamel & $1837-1839$ \\
\hline Navier & $1831-1832$ & & & Sturm & 1840-1850 \\
\hline Mathieu & $1833-1838$ & & & Delaunay & $1851-1871$ \\
\hline Liouville & $1839-1850$ & & & Belanger & $1851-1860$ \\
\hline Chasles & $1842-1850$ & & & Bour & $1861-1865$ \\
\hline Duhamel & $1851-1868$ & & & Philipps & $1866-1879$ \\
\hline Sturm & $1851-1855$ & & & Resal & 1872-1895 \\
\hline Bertrand & 1856-1894 & & & Bresse & $1880-1883$ \\
\hline Hermite & 1869-1876 & & & Sarrau & 1884-1895 \\
\hline Jordan & $1877-1911$ & & & Léauté & 1894-1904 \\
\hline Humbert & 1895-1920 & & & Lecornu & 1904-1927 \\
\hline Hadamard & 1912-1937 & & & Painlevé & 1905-1933 \\
\hline Lévy & 1920-1959 & & & Jouguet & $1927-1941$ \\
\hline Chapelon & 1937-1954 & & & Platrier & 1933-1952 \\
\hline Favard & 1954-1964 & & & Beghin & 1941-1948 \\
\hline Schwartz & 1959-1980 & & & Roy & 1948-1969 \\
\hline Mandel & 1952-1973 & & & & \\
\hline
\end{tabular}

6 See [Grabiner, 1981], [Belhoste, 1984], [Fraser, 1985], [Gilain, 1989], [Grattan-Guinness, 1990], [Bottazzini, 1992], [BradleySandifer, 2009], [Phili, 2012].

7 See [Gispert, 1982] and [Brechenmacher, 2016a].
8 Mechanics was not distinguished from analysis before 1832. 


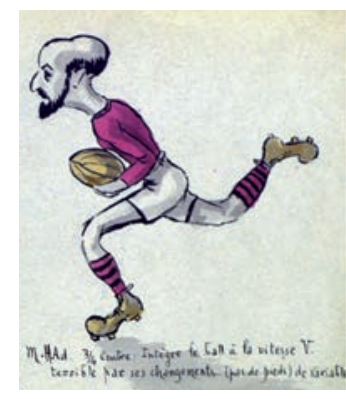

A caricature of Hadamard in Le petit crapal. () Collections École polytechnique.

The historical archives of the school contain a lot of information about the social activities of the students, including richly illustrated student journals, such as Le petit crapal (1896-1932), and the Séances des Ombres (1893-1929), which consisted of a theatre of Chinese shadows made of cardboard caricatures, accompanied by songs written and performed by the students, and which were often dedicated to the professors and their teaching.

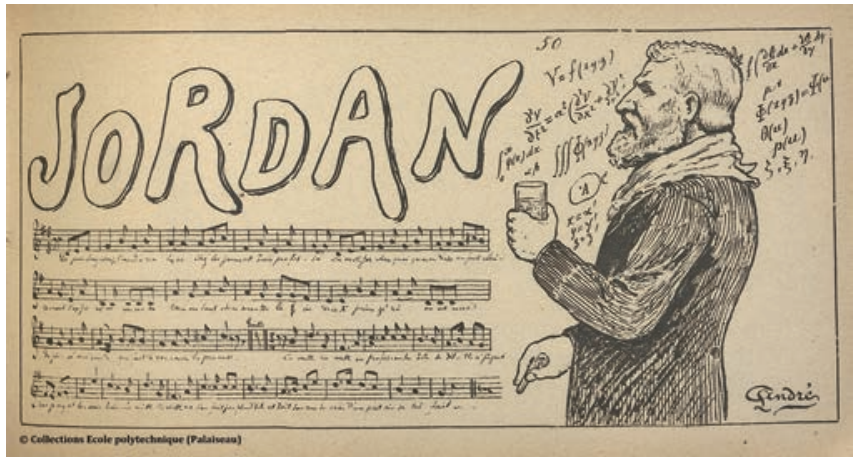

A caricature of Jordan's cours d'analyse for the Ombres in 1901. () Collections École polytechnique.

These archives provide rare and important sources for the history of mathematical education: while historians can usually make use of sources documenting the works of professors, and sometimes of students, the archives of the social activities of polytechnicians provide much rarer information, such as comments, caricatures and criticisms. This material especially sheds light on the reception by the students of the courses they were taught.

The archives of the students also highlight the central role played by mathematics in the construction of the persona of the polytechnicians. Often used to denote

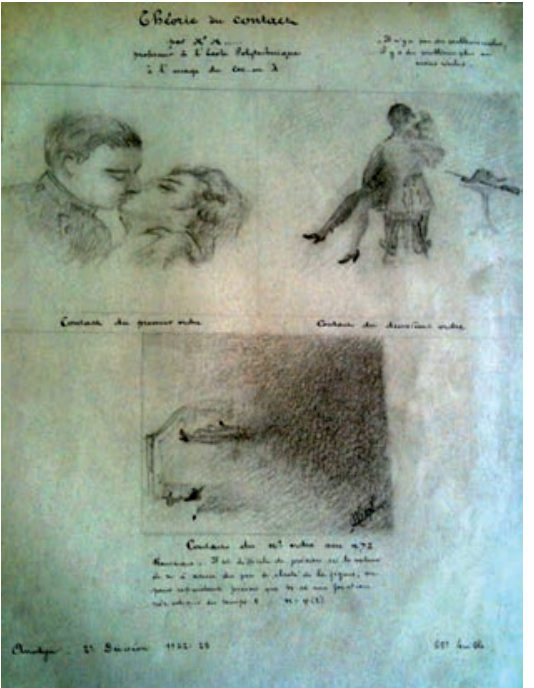

A caricature of the geometric theory of contact by a student of the promotion 1922. (C) Collections École polytechnique. the École, its students, or its alumni, the letter $\mathrm{X}$ can be seen as an allusion both to the traditional symbol of the unknown in an algebraic equation and to the crossing cannon displayed on its coat of arms, a reminder of the privileged links the École polytechnique always had with artillery. The students' academic slang expressions also highlight the central place of mathematics in the identity of polytechnicians, whose swords are, for instance, designated as "tangents". In contrast, foreign students, who did not have the right to wear a sword in the 19th century, used to be designated as "constants" because their tangent was equal to 0 . This central place of mathematics is especially made clear in the 19th century dictionary of student slang. At the entry "ana" (for analysis), a succession of anecdotes about the courses of Lagrange, Poisson, Ampère, Sturm and Hermite come to the following conclusion:

It is of the very importance devoted to the teaching of ana, which language is made of $x$ 's and $y$ 's, that comes the universal use of the nickname $X$ for designating the polytechnicians. Even though the polytechnicians do not always become mathematicians, all of them have enough knowledge in differential and integral calculus for the needs of the public services. At the most troubled times of our history, in 1830 and 1848, this knowledge has been particularly useful to distinguish the polytechnicians from all the individuals who costumed themselves in polytechnicians to pretend they aimed at maintaining order. When we met those, we asked them to differentiate $\sin x$ or $\log x$, and if they did not succeed to provide the right answer, we immediately sent them to jail [Albert-Lévy and Pinet, 1894, p. 25].

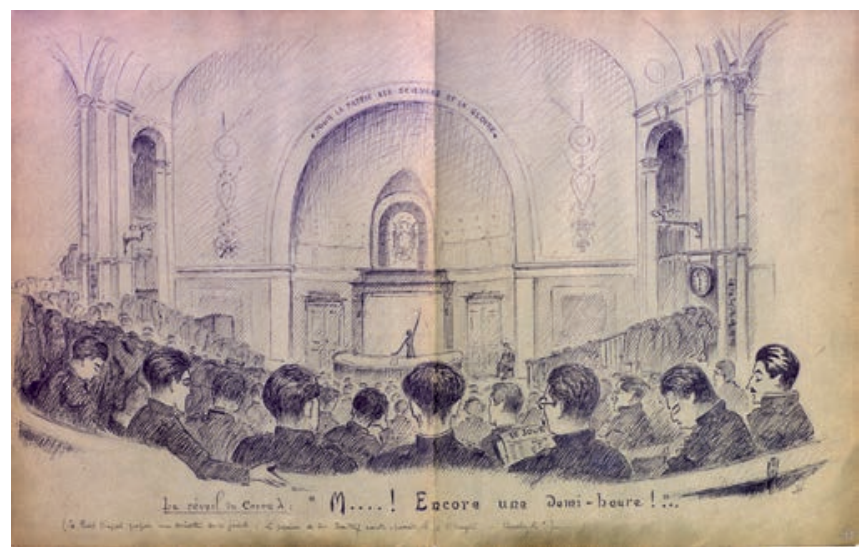

A drawing representing students sleeping during a plenary lecture at École polytechnique. (C) Collections École polytechnique.

École polytechnique has also maintained a collection of audio recordings, films, and videos. This collection dates back to the 1930s, even though most of the films were shot after the school was moved from Paris to Palaiseau in the 1970s. It documents a variety of activities, such as the students' military training, social activities, official events and scientific lectures. This audio-visual collection especially contains a great number of mathematics lectures after 1976, such as those of Laurent Schwartz, which have recently been digitalised. The collection also contains a number of films that were made by mathematicians at École polytechnique for other universities, as well as for private companies, in the 1980s and 1990s, and which especially document the development of mathematical models and computer simulations in those years. 


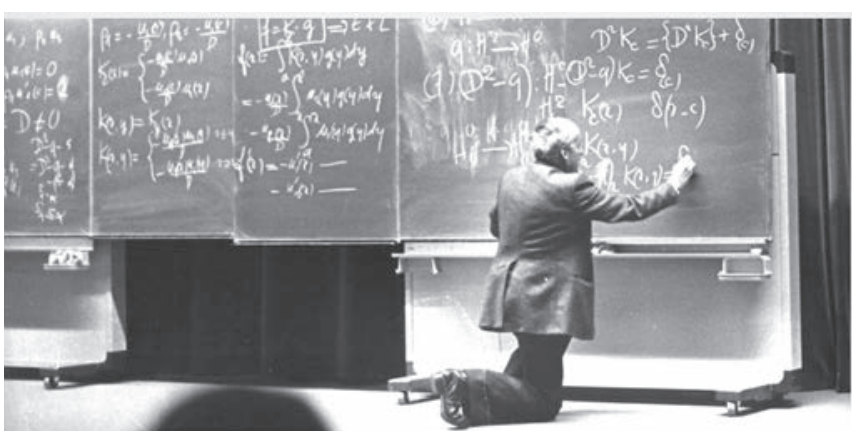

Screenshot of a lecture by Laurent Schwartz in 1976. (C) Collections École polytechnique.

The historical collections maintain a series of personal archive fonds, either donated to the school by professors or alumni, or purchased by alumni associations such as the AX (the association of alumni of École polytechnique) or the SABIX (the association of the friends of the school's library).

Among the archives donated by professors, we may cite three personal archive fonds especially relevant to the history mathematics: the ones of Camille Jordan, Maurice d'Ocagne, and Laurent Schwartz. The scientific correspondence of Camille Jordan contains about 200 letters sent to Jordan between 1867 and 1896, as well as a few drafts of letters written by Jordan himself [Billoux, 1985]. The epistolary exchanges with Brioschi, Cremona, Clebsch, Sylow, Kronecker, and Sylvester shed important light on Jordan's mathematical works on substitution groups and algebraic forms in the 1860s and 1870s, as well as on the reception of Jordan's 1870 Traité des substitutions et des équations algébriques. ${ }^{9}$ The correspond-

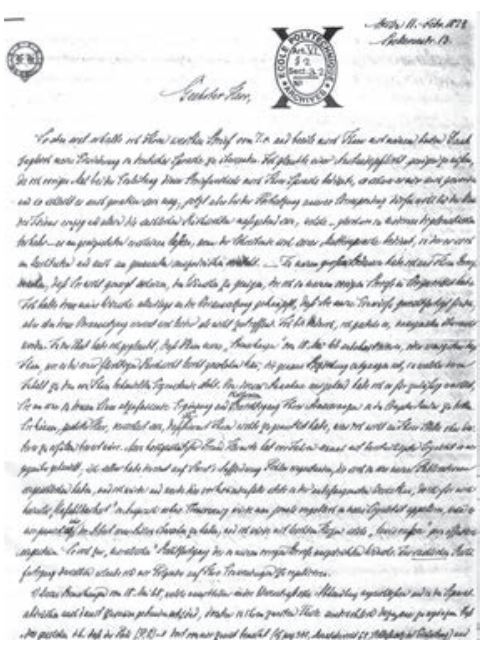

A letter from Leopold Kronecker to Jordan in 1874. (C) Collections École polytechnique. Fonds Camille Jordan. and 1890s documents the evolution of the three successive editions of Jordan's Cours d'analyse de l'École polytechnique, especially on issues relative to the foundations of analysis, such as with the interplay between Rolle's theorem and the mean values theorem [Gispert, 1982]. An important part of the correspondence is related to Jordan's editorial responsibilities as the director of the

\section{Personal archive fonds}

Journal de mathématiques pures et appliquées from 1884 to $1922 .{ }^{10}$ It includes discussions with the other directors of the main mathematical journals of the time, such as Klein in Göttingen, Gösta Mittag-Leffler in Stockholm, Paul Mansion in Ghent, and Giovanni Guccia in Palermo. Other letters shed light on various aspects of the organisation of mathematics in Paris in the late 19th century through the relationships between Jordan, Hermite, Jules Tannery, Halphen, and Humbert [Brechenmacher, 2016].

The personal archive fond of Maurice d'Ocagne is nine times bigger than the one of Jordan. Its inventory, which has only been done partially (on about one-third of the archive fond), gives access to about 500 manuscript documents that contain material related to Ocagne's lectures on geometry at École polytechnique as well as hundreds of letters from contemporary mathematicians, mostly in connection with Ocagne's mathematical works on geometry and with his editorial responsibilities for the Nouvelles annales de mathé-

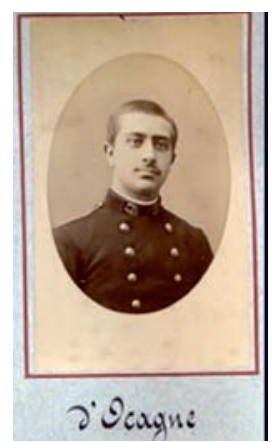

Ocagne in the picture album of his promotion. (C) Collections École polytechnique. matiques. This collection is complementary to the fonds Ocagne has deposited at other institutions: the Academy of science for his mathematical memoirs and notes, the École des ponts et chaussées for his mathematical works on nomography (including the part of his correspondence related to nomography and that Ocagne separated from the one on geometry he deposited at École polytechnique), ${ }^{11}$ the Conservatoire des arts et métiers for his collection of calculating devices, and the Department of Military Geography for the archives of the bureau of nomography that Ocagne directed during World War I. and Peano in the 1880 s

\footnotetext{
9 See [Brechenmacher, 2007a], [Brechenmacher, 2016a], [Brechenmacher, 2016b], [Lê, 2015].

$10 \mathrm{On}$ the creation of this journal by Liouville, see [Verdier, 2009]; on the direction of the journal by Jordan, see [Brechenmacher, 2009] and [Brechenmacher, 2016a].
}

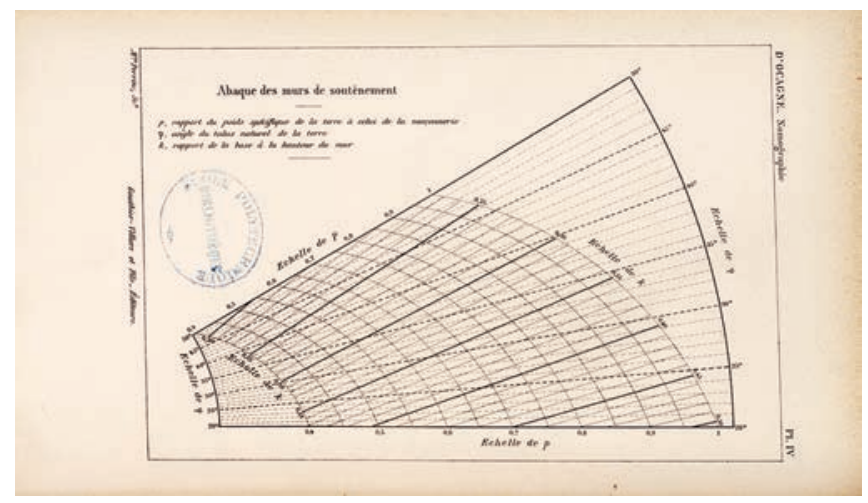

A nomogram. (C) Collections École polytechnique.

${ }^{11}$ Nomography is a mathematical theory that formalises a set of practical engineering techniques that developed in connection with the major programs of public works of the 19th century. It was, for instance, crucial for the earthwork required for constructing a railway or a canal to estimate embankments and excavations: these 'cut and fill' issues required fast calculations and practical precision, for which several instruments and graphical calculating devices were invented in the second half of the 19th century and were later applied to other issues, such as firing tables for cannon artillery. See [Tournès, 2014]. 
This fragmentation of personal archives in a variety of locations is quite typical of the French mathematicians of the 19th century, who used to accumulate several academic positions and who were therefore likely to deposit their archives in various places, such as the Academy of science, the Collège de France, École polytechnique, etc.

In contrast, Laurent Schwartz chose to deposit the whole of his personal archives at École polytechnique in 2002 [Guichardet, 2005]. Parts of these archives are public while others are still private and will not be made public until 2032, for certain archives, and 2062 for the whole collection. Schwartz's personal archive fond has been entirely inventoried and partially digitalised. ${ }^{12}$ It is organised in five sections :

- Mathematics: research and supervision of research

- Teaching material and material related to École polytechnique

- Issues related to scientific teaching and research in France and abroad

- Human rights defence

- Personal archives

The first section contains thousands of manuscripts consisting of mathematical research, notes taken during conferences, drafts of lectures and conferences on various topics, from abstract algebra to partial differential equations or stochastic processes on manifolds, as well as an extensive correspondence between Schwartz and other mathematicians. The second section especially documents Schwartz's teaching at École polytechnique, as well the creation in 1965 of the first research laboratory of mathematics in France, which Schwartz directed until 1983, and which is nowadays designated as Centre de mathématiques Laurent Schwartz. The third and fourth sections shed light on Schwartz's political and humanitarian commitments in France, Vietnam, USSR, Eastern Europe, Africa, or South America, especially with Schwartz's participation in the creations of the Audin Comittee during the Algerian war in 1957 and of the International Committee of Mathematicians in 1973. ${ }^{13}$ As a consequence of his opposition to the Algerian war, Schwartz was dismissed from École polytechnique in 1961, and reinstated in his position in 1963. New documents on this affair have been donated to the École polytechnique by Laurent Schwartz's daughter, Claudine Schwartz, on the occasion of an exposition organised in 2015 at the École polytechnique library for celebrating the centenary of the birth of Laurent Schwartz.

Several personal archive fonds have also been purchased by alumni associations. In 1974, the library acquired a collection of documents of Joseph-Louis Lagrange, one of the first professors of École polytechnique. This collection contains familial and biographical documents, a series of diplomas awarded to Lagrange by several academies, and a series of 37 letters sent by

\footnotetext{
${ }^{12}$ For accessing Schwartz's archive fond, see the database at the following link: https://bibli-aleph.polytechnique.fr.

${ }^{13}$ See [Paumier, 2014] and [Barany, 2016].
}

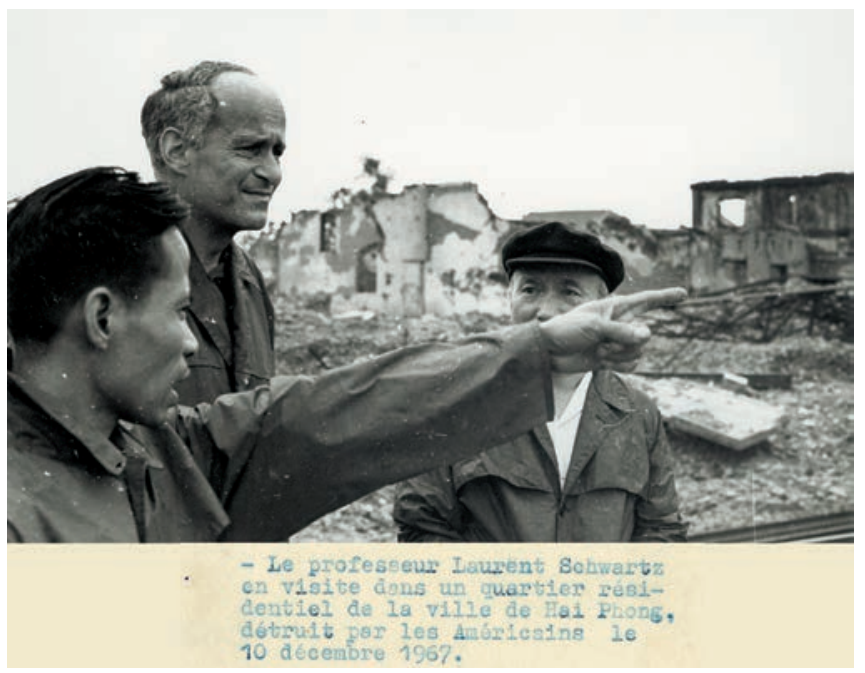

Laurent Schwartz in Vietnam. (C) Collections École polytechnique. Fonds Laurent Schwartz.

Lagrange to his father and his brother in Turin. ${ }^{14}$ This donation has enriched Lagrange's personal archive fond at École polytechnique, which includes several engravings, lithographies and paintings, as well as administrative archives. This fond has especially been exhibited to the public on the occasion of the bicentenary of Lagrange's death in 2013, ${ }^{15}$ and has provided the material for a documentary film produced by Institut Henri Poincaré. ${ }^{16}$

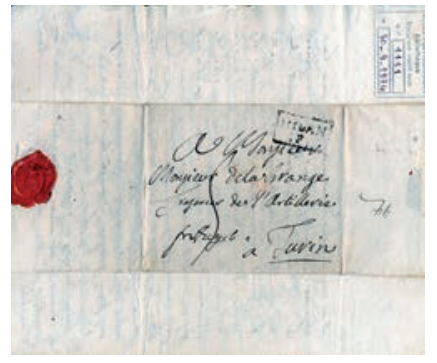

A letter from Lagrange to his father in 1777. (C) Collections École polytechnique.

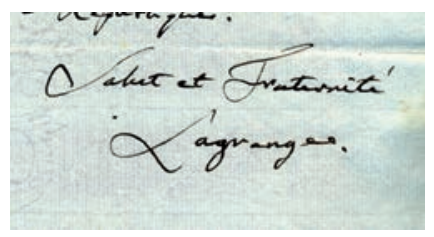

Lagrange's signature. (C) Collections École polytechnique.
In 2002 the alumni association AX purchased the personal archives of Gaspard Monge, which had until then remained in the possession of Monge's family. This extensive collection contains biographical documents, iconographic documents, Monge's correspondence, scientific manuscripts, and a variety of archives which document Monge's teaching as well as his political responsibilities [Thooris, 2007]. After it was donated to École polytechnique, the fond was inventoried by Marie Dupont, who has recently devoted a thesis to a critical edition of Monge's correspondence [Dupont, 2014], and a selection of Monge's scientific manuscripts has been digitalised. ${ }^{17}$ In 2018, Monge's archive fond was presented to the pub-

\footnotetext{
${ }^{14}$ For a description of these letters, see [Borgato and Luigi, 1989].

${ }^{15}$ A virtual edition of this exhibition can be visited at https://www. polytechnique.edu/bibliotheque/fr/lagrange-1736-1813-0.

16 This film can be watched on the video channel of Institut Poincaré.

${ }^{17}$ See http://numix.sabix.org/monge.html.
} 
lic in the first temporary exhibition of the mus'X, the new museum of École polytechnique: "Gaspard Monge, savant \& républicain. Quand les sciences forment les citoyens". 18
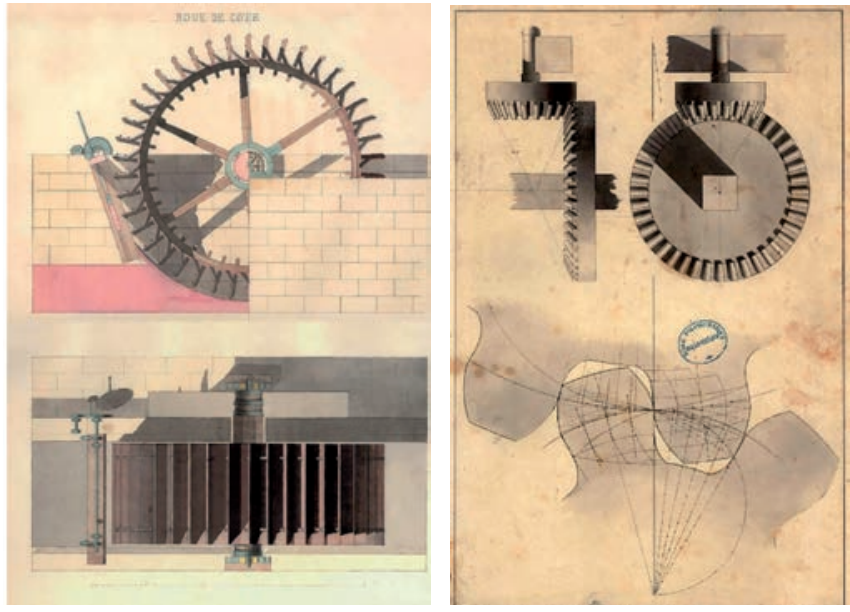

Drawings made by a student on applications of descriptive geometry to hydraulics and mechanics. (C) Collections École polytechnique.

Let us conclude this presentation by mentioning three personal archive fonds of mathematicians that have been donated to the École polytechnique library in the past decades: a collection of documents of Henri Poincaré, the personal archive fond of André Cholesky, and the correspondence of Gabriel Lamé. In 1977, François Poin-

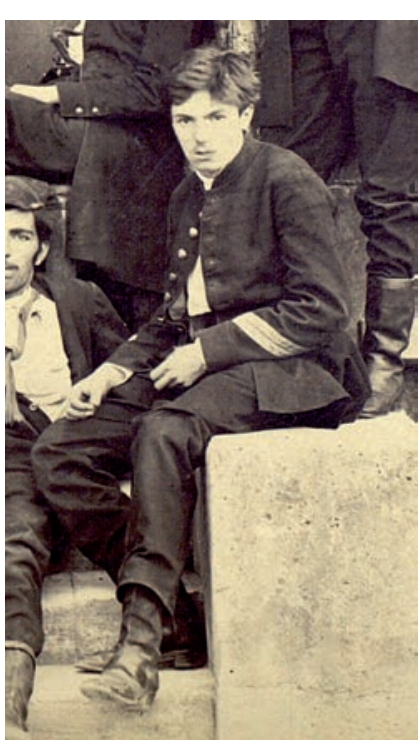

The young Henri Poincaré at École polytechnique. () Collections École polytechnique. caré donated to the library a copy of about 300 letters of his ancestor Henri Poincaré, along with the latter's tangent (i.e., polytechnician sword) and French Academy uniform. ${ }^{19}$ The letters consist of the correspondence between Henri Poincaré and his family while the former was a student at Polytechnique. These letters have been inventoried and digilitalised by the Archives Henri Poincaré in Nancy, ${ }^{20}$ and have recently been published with a critical edition by Laurent Rollet [Rollet, 2017].

The personal archive fond of André Cholesky was donated to the library by his grandson in 2003. These archives have been inventoried by the Centre of Historical Resources with the help of the mathematician Claude Brezinski. ${ }^{21}$ They especially

\footnotetext{
${ }^{18}$ See the following link: https://www.polytechnique.edu/bibliotheque/fr/exposition-temporaire-du-musix-gaspard-monge.

${ }^{19}$ See [Moatti, 2012] and [Azzola and Thooris, 2012].

${ }^{20}$ See the numerical platform devoted to Henri Poincaré's paper :http://henripoincarepapers.univ-lorraine.fr/.

21 See [Brezinski, 2005a], [Brezinski, 2005b], and [Brezinski, 2005c].
}

contain a manuscript, dated December 2, 1910, which provides the first known description of the Cholesky decomposition of a Hermitian positive-definite matrix. ${ }^{22}$

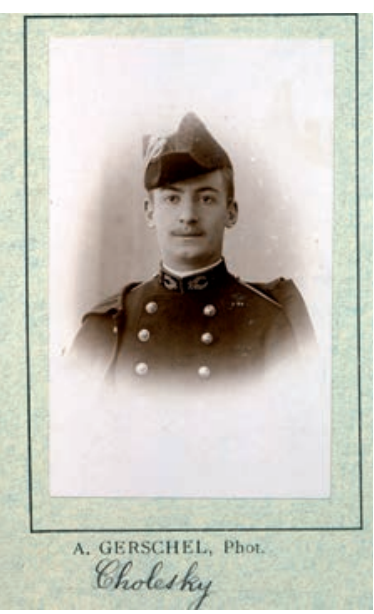

Cholesky in the picture album of his promotion in 1895 at Polytechnique.

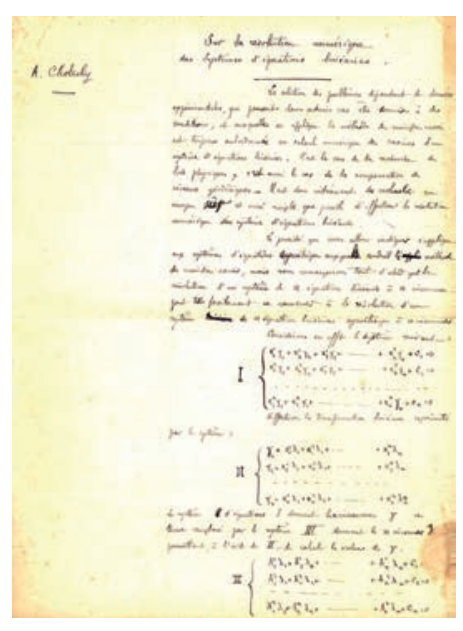

Cholesky's 1910 manuscript on the resolution of systems of linear equations. (1) Collections École polytechnique. Fonds André Cholesky.
In 2012, descendants of the mathematician Gabriel Lamé donated about 200 of his letters to the École library. This correspondence contains letters both from and to Lamé from 1815 to 1832 . It documents several aspects of the life of the mathematician, such as his training at École polytechnique as well as his service in Russia as an engineer from 1820 to 1831 [Gouzevitch, 2009].

\section{The historical collections: a resource for research, education, and popularisation of mathematics}

École polytechnique's historical collections are famous on a world scale in the field of the history of science and technology. The Centre of Historical Resource therefore welcomes researchers on a regular basis. The collections are especially a key resource for the LinX, École polytechnique's research laboratory in the humanities and social sciences, which brings together a wide range of scholars in the human, social, and natural sciences to support interdisciplinary research, teaching, and outreach on the roles of science, technology, medicine, and public health in past and present societies.

Historical collections are also an important source for developing innovative teaching initiatives. Since 2012, the Department of Humanities and Social Sciences at École polytechnique has promoted a project-oriented approach based on a direct contact with its patrimonial collections. This project-oriented approach aims to initiate students in research activity in the history of science and technology. The investigation into novel historical sources, such as archives or instruments which have never been studied before, allows students to contribute to contemporary research through various types of outcomes: research papers, indexes and digitalisation of

\footnotetext{
${ }^{22}$ See [Brezinski and Tournès, 2014]
} 
archival sources, software for the representation of historical data, exhibitions, documentary films, numerical models of ancient instruments, and other types of applications of mathematics to the development of mediation devices for museum collections.

A selection of student research projects are published on the numerical platform of the École polytechnique library on a regular basis. 23

Through these publications, the platform aims to shed light on various aspects of the historical collections as well as to enhance public understanding of science in relation to social concerns. The development of this numerical platform has recently given birth to the more ambitious project of giving access to all the historical collections of École polytechnique through a unified digital museum, which will moreover aim to provide e-learning resources on the history of science and technology, especially in the form of MOOCs targeting various types of audiences.

The recent creation of a physical museum, the mus'x, also works to enhance public understanding of science in relation to pressing social concerns. The development of both digital and physical museums makes available new historical sources and opens new perspectives for research in the fields of science, technology, and society. It calls for collective work from researchers both in science and technology and in the humanities and social sciences in order to construct platforms not only for research, but also for the diffusion of these historical sources to a much broader audience. Such diffusion of sources and research can inform contemporary research in the study of science in society, and, more generally, the general public.

\section{References}

[Albert-Lévy and Pinet, 1894] Lévy, A. and Pinet, G. (1894). L'argot de l'X: illustré par les $X$. E. Testard, Paris.

[Azzola, 2013] Azzola, O. (2013). Deux cents ans d'archives à l'École polytechnique: du comptable aux archivistes. La Gazette des archives, 231:63-76.

[Azzola and Thooris, 2012] Azzola, O. and Thooris, M.-C. (2012). L'École polytechnique honore la mémoire d'Henri Poincaré. Bulletin de la Société des amis de la Bibliothèque de l'École polytechnique, 51:41-44.

[Azzola and Verdier, 2010] Azzola, O. and Verdier, N. (2010). Extraits choisis du "fonds Drouineau / Liouville". Bulletin de la Société des amis de la Bibliothèque de l'École polytechnique, 45:17-22.

[Barany, 2016] Barany, M. (2016). Distributions in Postwar Mathematics. $\mathrm{PhD}$ thesis, Princeton University.

[Belhoste, 1985] Belhoste, B. (1984-1985). Le Cours d'analyse de Cauchy à l'Ecole polytechnique en seconde année. Sciences et techniques en perspective, 9:101-178.

[Belhoste, 1994] Belhoste, B. (1994). Un modèle à l'épreuve. L'École polytechnique de 1794 au Second Empire. In Belhoste, B., Dahan Dalmedico, A. and Picon, A., editors: Un modèle à l'épreuve. L'École polytechnique de 1794 au Second Empire, pages 9-30. Dunod, Paris.

[Belhoste, 1998] Belhoste, B. (1998). De l'École polytechnique à Saratoff, les premiers travaux géométriques de Poncelet. Bulletin de la Société des amis de la Bibliothèque de l'École polytechnique, 19:929.

\footnotetext{
${ }^{23} \mathrm{See}$ https://www.polytechnique.edu/bibliotheque/fr/portailpatrimoine-de-lecole-polytechnique.
}

[Belhoste, 2001] Belhoste, B. (2001). The École polytechnique and Mathematics in Nineteenth-Century France. In Bottazzini, U. and Dahan, A., editors: The École polytechnique and Mathematics in Nineteenth-Century France. Routlege, London.

[Belhoste, 2002] Belhoste, B. (2002). Anatomie d'un concours. L'organisation de l'examen d'admission à l'École polytechnique de la Révolution à nos jours. Histoire de l'éducation, 94:141-175.

[Billoux, 1985] Billoux, C. (195). Le nouveau classement thématique des archives de l'École polytechnique. Revue d'histoire des sciences, 38(1):73-82.

[Billoux, 1985] Billoux, C. (1985). La correspondance mathématique de C. Jordan dans les archives de l'École polytechnique. Historia Mathematica, 12:80-88.

[Billoux, 1989] Billoux, C. (1989). Les archives de l'École polytechnique. La Gazette des archives, 145:125-135.

[Billoux, 1999] Billoux, C. (1999). La résurrection des archives. Bulletin de la Société des amis de la Bibliothèque de l'École polytechnique, 22:1-9.

[Borgato and Luigi, 1989] Borgato, M. T. and Luigi, P. (1989). The family letters of Joseph-Louis Lagrange. Bollettino di Storia delle Scienze Matematiche, 2:192-318.

[Bottazzini, 1992] Bottazzini, U. (1992). Geometrical rigour and 'modern analysis', an introduction to Cauchy's Cours d'analyse. In Cauchy, A.-L., editor: Cours d'analyse de l'École royale polytechnique, 1ère partie, Analyse algébrique. CLUEB, Bologna.

[Bradley and Sandifer, 2009] Bradley, R. and Sandifer, C. (2009). Cauchy's Cours d'analyse: An Annotated Translation. Springer, New York.

[Brechenmacher, 2007] Brechenmacher, F. (2007). La controverse de 1874 entre Camille Jordan et Leopold Kronecker. Revue d'histoire des mathématiques, 13:187-257.

[Brechenmacher, 2009] Brechenmacher, F. (2009). Le 'journal de M. Liouville' sous la direction de Camille Jordan (1885-1922). Bulletin de la Sabix, 45:65-71.

[Brechenmacher, 2016a] Brechenmacher, F. (2016a). The 27 Italies of Camille Jordan. In Brechenmacher, F., Jouve, G., Mazliak, L. and Tazzioli, R., editors: Images of Italian Mathematics in France, pages 45-91. Springer.

[Brechenmacher, 2016b] Brechenmacher, F. (2016b). Algebraic generality vs arithmetic generality in the controversy between C. Jordan and L. Kronecker (1874). In Chemla, K., Chorlay, R. and Rabouin, D., editors: The Oxford Handbook of Generality in Mathematics and the Sciences, pages 433-467. Oxford University Press.

[Brezinski, 2005a] Brezinski, C. (2005a). Géodésie, topographie et cartographie. Bulletin de la Société des amis de la Bibliothèque de l'École polytechnique, 39:32-66.

[Brezinski, 2005b] Brezinski, C. (2005b). Restitution du carnet no 2 de cholesky. Bulletin de la Société des amis de la Bibliothèque de l'École polytechnique, 39:68-74.

[Brezinski, 2005c] Brezinski, C. (2005c). Restitution du carnet no 3 de cholesky. Bulletin de la Société des amis de la Bibliothèque de l'École polytechnique, 39:75-79.

[Brezinski and Tournès, 2014] Brezinski, C. and Tournès, D. (2014). André-Louis Cholesky. Mathematician, Topographer and Army Officer. Birkhäuser, Basel.

[Chabert and Gilain, 2004] Chabert, J.-L. and Gilain, C. (2004). Debating the Place of Mathematics at the École polytechnique around World War i. In Aubin, D. and Goldstein, C., editors: The War of Guns and Mathematics: Mathematical Practices and Communities in France and Its Western Allies around World War I, pages 275-306. American Mathematical Society, Providence.

[Dupont, 2014] Dupont, M. (2014). Édition de la correspondance de Gaspard Monge (1795-1799): ce qu'elle révèle de l'engagement public d'un géomètre au cours de la Révolution française. $\mathrm{PhD}$ thesis, University of Athens. 
[Fraser, 1985] Fraser, C. (1985). J. L. Lagrange's changing approach to the foundations of the calculus of variations. Archive for History of Exact Sciences, 32(2):151-191.

[Gentil, 2002] Gentil, B. (2002). Les notes de cours d'Auguste Comte, élève à l'École polytechnique (1814-1816). Bulletin de la Société des amis de la Bibliothèque de l'École polytechnique, 30:51-56.

[Gierster, 1989] Gierster, J. (1989). Cauchy et le Cours d'Analyse de l'Ecole polytechnique. Bulletin de la Société des amis de la Bibliothèque de l'École polytechnique, 5:3-145.

[Gispert, 1982] Gispert, H. (1982). Camille Jordan et les fondements de l'analyse. Thèse de doctorat, Université Paris-Sud.

[Gouzévitch and Gouzévitch, 2009] Gouzévitch, I. and Gouzévitch, D. (2009). Gabriel Lamé à Saint-Pétersbourg (1820-1831). Bulletin de la Société des amis de la Bibliothèque de l'École polytechnique, 44:20-43.

[Grabiner, 1981] Grabiner, J. V. (1981). The Origins of Cauchy's Rigorous Calculus. The MIT Press, Cambridge.

[Grattan-Guinness, 1990] Grattan-Guinness, I. (1990). Convolutions in French Mathematics, 1800-1840: From the Calculus and Mechanics to Mathematical Analysis and Mathematical Physics. Birkhäuser, Basel.

[Grattan-Guinness, 2005] Grattan-Guinness, I. (2005). The "Ecole Polytechnique", 1794-1850: Differences over Educational Purpose and Teaching Practice. The American Mathematical Monthly, 112(3):233-250.

[Guichardet, 2005] Guichardet, A. (2005). Laurent Schwartz et l'Ecole polytechnique. Bulletin de la Société des amis de la Bibliothèque de l'École polytechnique, 39.

[Lê, 2015] Lê, F. (2015). Geometrical equations: Forgotten premises of Felix Klein's Erlanger Programm. Historia Mathematica, 42(3):315-342.

[Moatti, 2012] Moatti, A. (2012). Les lettres personnelles de Poincaré à sa famille pendant sa scolarité à Polytechnique. Bulletin de la Société des amis de la Bibliothèque de l'École polytechnique, 51:32-36.

[Paumier, 2014] Paumier, A.-S. (2014). Laurent Schwartz (1915-2002) et la vie collective des mathématiques. Thèse de doctorat, Université Paris 6.

[Phili, 2012] Phili, C. (2012). Le manuscrit du cours de Lagrange à l'École polytechnique (1797-1798). In Féry, S., editor: Aventures de l'analyse de Fermat à Borel. Mélanges en l'honneur de Christian Gilain. Presses universitaires de Nancy, Nancy.

[Rollet, 2017] Rollet, L., editor (2017). La correspondance de jeunesse d'Henri Poincaré. Les années de formation. De l'École polytechnique à l'École des Mines (1873-1878). Birkhäuser.

[Thooris, 2007] Thooris, M.-C. (2007). L'iconographie du fonds Monge: un inventaire singulier. Bulletin de la Société des amis de la Bibliothèque de l'École polytechnique, 41.

[Tournès, 2014] Tournès, D. (2014). Mathematics of engineers: Elements for a new history of numerical analysis. Proceedings of the International Congress of Mathematicians, 4:1255-1273.

[Verdier, 2009] Verdier, N. (2009). Le journal de Liouville et la presse de son temps: une entreprise d'édition et de circulation des mathématiques au XIXe siècle (1824-1885). Thèse de doctorat, Université Paris-Sud.

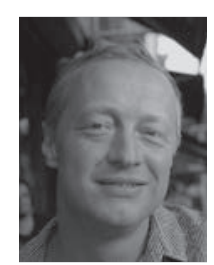

Frédéric Brechenmacher [frederic.brechenmacher@polytechnique.edu] is a professor of the history of science at École Polytechnique. His research activities are devoted to the history of algebra from the 18th century to the 20th century. He recently supervised the creation of a science museum at École Polytechnique: the mus'x. 